\title{
Spider Communities and Biological Control in Native Habitats Surrounding Greenhouses
}

\author{
Belén Cotes ${ }^{1}$, Mónica González ${ }^{2}$, Emilio Benítez ${ }^{3}{ }^{\circledR 0}$, Eva De Mas ${ }^{4}$, Gemma Clemente-Orta ${ }^{2}$, \\ Mercedes Campos ${ }^{3}$ and Estefanía Rodríguez ${ }^{5, *}$ \\ 1 Department of Plant Protection Biology, Swedish University of Agricultural Sciences, 23053 Alnarp, \\ Sweden; belen.ramal@plen.ku.dk \\ 2 Estación Experimental Cajamar, El Ejido, 04710 Almeria, Spain; \\ monicagonzalez@fundacioncajamar.com (M.G.); gemma.clemente@pvcf.udl.cat (G.C.-O.) \\ 3 Department of Environmental Protection, Estación Experimental del Zaidín, CSIC, 18008 Granada, \\ Spain; emilio.benitez@eez.csic.es (E.B.); mercedes.campos@eez.csic.es (M.C.) \\ 4 Department of Functional and Evolutionary Ecology, Estación Experimental de Zonas Aridas, \\ CSIC, 04120 Almeria, Spain; evademas@gmail.com \\ 5 IFAPA, Centro La Mojonera, 04745 Almeria, Spain \\ * Correspondence: mestefania.rodriguez@juntadeandalucia.es; Tel.: +34-671-532-037
}

Received: 19 January 2018; Accepted: 10 March 2018; Published: 14 March 2018

\begin{abstract}
The promotion of native vegetation as a habitat for natural enemies, which could increase their abundance and fitness, is especially useful in highly simplified settings such as Mediterranean greenhouse landscapes. Spiders as generalist predators may also be involved in intra-guild predation. However, the niche complementarity provided by spiders as a group means that increased spider diversity may facilitate complementary control actions. In this study, the interactions between spiders, the two major horticultural pests, Bemisia tabaci and Frankliniella occidentalis, and their naturally occurring predators and parasitoids were evaluated in a mix of 21 newly planted shrubs selected for habitat management in a highly disturbed horticultural system. The effects of all factors were evaluated using redundancy analysis (RDA) and the generalized additive model (GAM) to assess the statistical significance of abundance of spiders and pests. The GAM showed that the abundance of both pests had a significant effect on hunter spider's abundance, whereas the abundance of $B$. tabaci, but not F. occidentalis, affected web-weavers' abundance. Ordination analysis showed that spider abundance closely correlated with that of B. tabaci but not with that of F. occidentalis, suggesting that complementarity occurs, and thereby probability of biocontrol, with respect to the targeted pest $B$. tabaci, although the temporal patterns of the spiders differed from those of F. occidentalis. Conservation strategies involving the establishment of these native plants around greenhouses could be an effective way to reduce pest populations outdoors.
\end{abstract}

Keywords: beneficial arthropods; GAM; habitat manipulation; RDA; tobacco whitefly; western flower thrips

\section{Introduction}

Biodiversity in agro-ecosystems can enhance ecosystem pest control, which can potentially reduce the reliance on chemical inputs such as pesticides [1-3]. Perennial non-crop habitats are thought to play a crucial role in maintaining the natural enemies (NEs) of pest populations in agricultural landscapes. Semi-natural habitats can provide shelter, floral food resources (nectar and/or pollen), alternative prey and hosts $[4,5]$. However, various studies have recorded neutral, positive and negative relationships between NEs biodiversity and the resulting effectiveness of biological control (BC), caused by functional redundancy, niche complementarity and intra-guild predation (IGP), respectively $[6,7]$. 
Successful management of this ecosystem service therefore depends on the development of appropriate plant diversity rather than an increase in the number of plant species per se $[4,5]$.

In conventional agriculture systems, which are highly dependent on synthetic inputs, biodiversity is usually limited, which, in turn, limits the ability to provide BC services $[1-3,8]$. Intensive greenhouse horticulture is located in the most arid regions of the Mediterranean Basin. The province of Almeria (SE Spain) is the most dominant horticultural region in Europe encompassing 30,000 ha of plastic greenhouses [9]. Economic development in this region has been prioritized over long-term environmental issues, which has resulted in the loss of native perennial vegetation and considerable fragmentation [10].

The tobacco whitefly, Bemisia tabaci (Gennadius) (Homoptera: Aleyrodidae), and the western flower thrips, Frankliniella occidentalis (Pergande) (Thysanoptera: Thripidae), are the insect pest species most commonly found in this horticultural system. These are, by far, the most problematic pests, given their polyphagous habits and their capacity to transmit a large number of plant viruses [11]. Integrated Pest Management (IPM) practices have been adopted by a majority of growers since 2008, and use of effective native NEs plays an important role in pest control [12-15]. According to local government data, biological control plays a vital role in about $80 \%$ of the greenhouse crops in Almeria. In this less pesticide-dependent context, some strategies have been proposed. For example, hedgerows containing native shrubs can be established between greenhouses to promote biodiversity and ecosystem services $[16,17]$. In fact, it is known that native flora may act as suitable habitat for beneficial insects in agroecosystems [18-21]. In this sense, authors found that native shrubs surrounding greenhouses in Almeria are unsuitable as reservoirs for plant virus [17]. In addition, some native shrubs have also been identified as hosts of the two main pests and their specifics NEs [22]. However, the function of these native shrubs as suitable habitat for other important predators like spiders remains unknown.

As a major predator group, spiders (Araneae), which feed on terrestrial arthropod communities, are one of the most abundant, diversified and ubiquitous populations in both natural and agricultural habitats $[23,24]$. Spiders, whose role as BC agents in agroecosystems have been well documented, can also have significant top-down effects [25-27]. Spider assemblages can offer a complementary niche to attack different pest species or subsets of the same pest species [28]. Similarly, their predator foraging behaviour has a variety of indirect effects on other species and, ultimately, on plant communities [29]. The current status of spiders as generalist predators could limit their biocontrol potential due to their involvement in IGP $[30,31]$. Therefore, apart from the potential for intra-guild predation, a diversified assemblage of spiders may exert a natural biological control. Some studies have shown that whiteflies and thrips make up a spider's diet in some crops [32-37]. Data on spider diversity in arid areas of SE Spain indicate that spider assemblages are highly diverse [38]. However, the impact of spider communities existing in and interacting with native shrubs surrounding greenhouses is unknown. Spiders may represent potential biological agents for the main horticultural pests, or maybe a risk to the conservation of key NEs. Therefore, the aim of this study was (1) to identify native plants that support spider guilds and (2) to assess the specific relationships between spider guilds, pests and other NEs. This is a necessary first step for future research based on selection of plants for increasing biocontrol services by spiders outside the greenhouses in order to reduce the pest population and decrease their ability to colonize the greenhouses.

\section{Materials and Methods}

\subsection{Study Area and Plant Species}

Field surveys were conducted at Cajamar Experimental Station in the province of Almeria, Spain, at $36^{\circ} 48^{\prime} \mathrm{N}, 2^{\circ} 3^{\prime} \mathrm{W}$ and at an elevation of $\sim 155 \mathrm{~m}$. The experimental field was divided into 4 plots $(17 \times 10 \mathrm{~m})$ separated by four walkways with a width of 1-2 $\mathrm{m}$ that were kept bare [22]. In December 2010, we established a semi-arid shrubland patch with a pool of 21 plant species approximately three 
years old in each plot and belonging to 12 different botanical families. Each plant species was replicated in a different ratio according to its size (Table 1). The design aims to reproduce the natural environment. The ratio was approximately: shrubs at $1 \mathrm{~m}$ (ratio 1:1), small shrubs at $0.5 \mathrm{~m}$ (ratio 2:1) and ground cover species at $0.30 \mathrm{~m}$ (ratio 3:1). This allows for creating a range of vegetation strata. The experimental design included nectar-rich plants (8 species), pollen-rich plants (6 species) and pollen-nectar-rich plants (7 species). For the purposes of plant selection, other criteria were also considered using a ranking system based on the following criteria [16]: (1) overlapping bloom periods, (2) non-hosting horticultural virus diseases [17], (3) as well as morphology and colour. All plots were manually weeded during the study. The field was located in an area completely surrounded by greenhouses in the size range of 1000-2000 $\mathrm{m}^{2}$, and with different vegetable production including: tomato, pepper and cucumber. The neighbouring horticultural crops were managed under an integrated pest management regime with an emphasis on augmentative BC. The NEs, which are mass-reared and widely commercialized in the study area, included: the whitefly parasitoid Eretmocerus spp. (Hymenoptera: Aphelinidae), the whitefly predator Nesidiocoris tenuis (Reuter) (Hemiptera: Miridae), the aphid parasitoid Aphidius colemani, as well as the thrips predators Orius laevigatus (Hemiptera: Anthocoridae) and the predatory mite Amblyseius swirskii (Acari: Phytoseiidae).

Table 1. Native shrub species selected for habitat management in Mediterranean greenhouse areas.

\begin{tabular}{|c|c|c|c|c|}
\hline Species Assayed & Common Name & Family & Plant Code & Number Assayed \\
\hline Ephedra fragilis Desf. & joint pine & Ephedraceae & Ef & 7 \\
\hline Genista umbellata Poir. & bolina & Fabaceae & $\mathrm{Gu}$ & 7 \\
\hline Macrochloa tenacissima (L.) Kunth & alfa grass & Poaceae & Mt & 9 \\
\hline Myrtus communis L. & myrtle & Myrtaceae & Mc & 7 \\
\hline Olea europaea var. sylvestris L. & wild olive tree & Oleaceae & Oe & 3 \\
\hline Phillyrea angustifolia L. & false olive & Oleaceae & Pha & 10 \\
\hline Dorycnium pentaphyllum Scop. & prostrate canary clover & Fabaceae & Dp & 6 \\
\hline Lavandula latifolia Medik. & spike lavender & Lamiaceae & $\mathrm{Li}$ & 6 \\
\hline Lycium intricatum Boiss. & cambrón & Solanaceae & $\mathrm{Li}$ & 4 \\
\hline Phlomis purpurea L. & purple phlomis & Lamiaceae & $\mathrm{Pp}$ & 2 \\
\hline Rosmarinus officinalis L. & rosemary & Lamiaceae & Ro & 25 \\
\hline Thymus hyemalis Lange. & winter thyme & Lamiaceae & Th & 17 \\
\hline Thymus vulgaris L. & thyme & Lamiaceae & $\mathrm{TV}$ & 19 \\
\hline Viburnum tinus L. & laurustinus & Adoxaceae & $\mathrm{Vt}$ & 4 \\
\hline Anthyllis cytisoides L. & albaida & Fabaceae & Ac & 2 \\
\hline Crithmum maritimum L. & rock samphire & Apiaceae & $\mathrm{Cm}$ & 6 \\
\hline Dittrichia viscosa (L.) Greuter & false yellowhead & Asteraceae & Dv & 2 \\
\hline Periploca angustifolia Labill. & cornical & Asclepiadaceae & Pea & 6 \\
\hline Retama sphaerocarpa (L.) Boiss. & yellow broom & Fabaceae & Rs & 3 \\
\hline Rhamnus lycioides subsp. lycioides L. & Mediterranean buckthorn & Rhamnaceae & $\mathrm{Rl}$ & 10 \\
\hline Whitania frutescens (L.) Pauquy. & oroval & Solanaceae & Wf & 6 \\
\hline
\end{tabular}

\subsection{Arthropod Collection}

After 18 months, when the native plants were well established, the sampling of arthropods was carried out in 161 plants once a month between June 2012 and June 2013 [22]. Arthropods from each plant were vacuumed for $40 \mathrm{~s}$ with the aid of a Stihl ${ }^{\circledR} \mathrm{SH} 85 \mathrm{C}$ blower [18]. Among the diverse range of arthropods collected, the primary focus was on spiders, the two horticultural pests B. tabaci and F. occidentalis and their naturally occurring NEs: N. tenuis, O. laevigatus, Eretmocerus spp., the thrips parasitoid Ceranisus spp. (Hymenoptera: Eulophidae) and the thrips predator Aeolothrips spp. (Thysanoptera: Aeolothripidae). Juvenile spiders were taxonomically sorted by family, the adults by species, and, where possible, by morphospecies. They were also sorted by functional group into web-weaver and hunter spiders (the latter involved in non-web foraging) [35].

\subsection{Statistical Analysis}

Data analysis began with data exploration [39]. Boxplots were used to show the abundance of the different arthropod groups in each plant species. A scatterplot of spider abundance clearly 
showed a non-linear temporal pattern; non-linear patterns were also found in the residuals when linear regression was applied. Total abundance of spiders was modelled as a function of four covariates by fitting a generalized additive model (GAM) with a Poisson distribution and the logistic link function $\log \left(\pi_{i}\right)=\eta_{i}$. The GAM can handle a combination of parametric and nonparametric variables [40], allowing for non-linear relationships between the response variables and all or some explanatory variables. Two separate GAMs were constructed with abundance of hunter and web-weaver spiders as response variables. The covariates used in the predictor function $\left(\eta_{i}\right)$ were a group of twenty-one plant species, whitefly abundance, thrips abundance and smoothing function of time (sampling month). Thus, the Poisson GAM for hunter spiders is specified below:

$$
\begin{gathered}
\text { Hunters }_{i} \sim \operatorname{Poisson}\left(\mu_{i}\right) \\
E\left(\text { Hunters }_{i}\right)=\operatorname{var}\left(\text { Hunters }_{i}\right)=\mu_{i} \\
\log \left(\mu_{i}\right)=\alpha+\beta_{1} \times \text { Plant species }_{i}+\beta_{2} \times \text { Whitefly abundance }_{i}+\beta_{3} \times \text { Thrips abundance }_{i}+f\left(\text { Time }_{i}\right)
\end{gathered}
$$

The Poisson GAM for web-weaver spiders is given below:

$$
\begin{aligned}
& \text { Web-weavers } i \text { Poisson }\left(\mu_{i}\right) \\
& E\left(\text { Web-zeavers }_{i}\right)=\operatorname{var}\left(\text { Web-weavers }_{i}\right)=\mu_{i} \\
& \log \left(\mu_{i}\right)=\alpha+\beta_{1} \times \text { Plant species }_{i}+\beta_{2} \times \text { Whitefly abundance }_{i}+\beta_{3} \times \text { Thrips abundance }_{i}+f\left(\text { Time }_{i}\right)
\end{aligned}
$$

The models were built using R software [41] and were implemented with the aid of the mgvc package [42]. Overdispersion, which was determined by the sum of the squared Pearson residuals, divided by the residual degree of freedom, was found to be less than 2 in all models presented.

To graphically represent multivariate arthropod composition patterns, the redundancy analysis (RDA) ordination technique was used to determine the relationships between the three arthropod groups (insect pests, NEs and spiders) and explanatory variables (plant species and sampling month). The results are displayed graphically in an RDA correlation triplot using the vegan package [42].

\section{Results}

\subsection{Spider Composition in Native Plants}

A total of 1301 spiders were collected during the sampling period. While five families of web-weavers were collected throughout the study, the species, Neoscona subfusca, constituted the most abundant spider in native plants. Hunters were composed of six families, with Salticidae, Thomisidae and Philodromidae predominating among the captures (Table 2).

Spider abundance levels were higher in certain native plants (Table 3). Similarly, there were seasonal differences in the distribution of spiders (hunters and web-weavers) over time (Table 3). The highest level of pests was recorded outside when maximum temperatures were $31.3^{\circ} \mathrm{C}$ and $20.9^{\circ} \mathrm{C}$ for whitefly and thrips, respectively. Hunters were more abundant when maximum was $35.8{ }^{\circ} \mathrm{C}$ whereas web-weavers were abundant at $27.4{ }^{\circ} \mathrm{C}$. Overall, the abundance of spiders was higher in a group of eleven plant species, consisting of A. cytisoides, C. martimum, D. viscosa, E. fragilis, G. umbellata, L. intricatum, O. europaea, P. purpurea, R. sphaerocarpa, R. officinalis and T. vulgaris, than in the other plant species (Figure 1). In particular, two native plants, A. cytisoides and T. vulgaris, supported a larger number of hunters, while web-weavers were more abundant in E. fragilis, O. europaea and R. sphaerocarpa (Figure 1). Only five plant species, G. umbellata, R. officinalis, T. vulgaris, A. cytisoides and D. viscosa, showed a high occurrence of both spiders and pests (Figure 1). The results generated by the models used indicate that the abundance of $B$. tabaci and F. occidentalis had a significant effect on the occurrence of hunters (Table 3). Similarly, the abundance of B. tabaci, but not F. occidentalis, had a significant impact on web-weavers (Table 3). 
Table 2. Frequency (\%) of spiders collected in 21 newly planted shrubs established in a highly disturbed horticultural system.

\begin{tabular}{cc}
\hline Taxa & Frequency (\%) \\
\hline Web-weavers & 50.6 \\
Juveniles & 13.1 \\
Araneidae [Neoscona subfusca] & 78.7 \\
Araneidae (sp. 1 sp. 2 sp. 3) & 4.7 \\
Theridiidae [Anelosimus aulicus] & 1.5 \\
Linyphiidae/Tetragnatidae/Pholcidae & 2.0 \\
Hunting spiders & 49.4 \\
Salticidae [Thyene imperialis] & 23.2 \\
Salticidae [Heliophanus aeneus] & 13.7 \\
Thomisidae [Xysticus kochi] & 20.8 \\
Thomisidae [Thomisus onustus] & 4.7 \\
Thomisidae [Xysticus bufo] & 0.6 \\
Oxyopidae [Oxyopes spp.] & 10.0 \\
Oxyopidae [Peucetia viridans] & 0.5 \\
Philodromidae [Pulchellodromus spp.] & 21.1 \\
Philodromidae [Philodromus dispar] & 4.5 \\
Liocranidae/Lycosidae & 0.9 \\
\hline
\end{tabular}

Table 3. Results of the Generalized Additive Model (GAM) analysing the abundance of spider guilds in 21 native shrubs with different abundance of pests and sampling period as covariates.

\begin{tabular}{|c|c|c|c|c|c|c|c|}
\hline Model & Types of Variables & Variables & Estimate & SE & $x^{2}$ & df & $p$ Value \\
\hline \multirow{4}{*}{ Hunter spiders } & Numerical & Whitefly abundance & 0.015 & 0.005 & 18.771 & 1 & $<0.001$ \\
\hline & Numerical & Thrips abundance & -0.005 & 0.004 & 7.943 & 1 & $<0.01$ \\
\hline & Categorical & Plant species & & & 193.792 & 20 & $<0.001$ \\
\hline & Smoothed & Month of sampling & & & 113.1 & 8.35 & $<0.001$ \\
\hline \multirow{4}{*}{ Web-weavers } & Numerical & Whitefly abundance & 0.014 & 0.007 & 4.0544 & 1 & $<0.05$ \\
\hline & Numerical & Thrips abundance & -0.004 & 0.004 & 0.782 & 1 & 0.3765 \\
\hline & Categorical & Plant species & & & 164.204 & 20 & $<0.001$ \\
\hline & Smoothed & Month of sampling & & & 336 & 8.89 & $<0.001$ \\
\hline
\end{tabular}
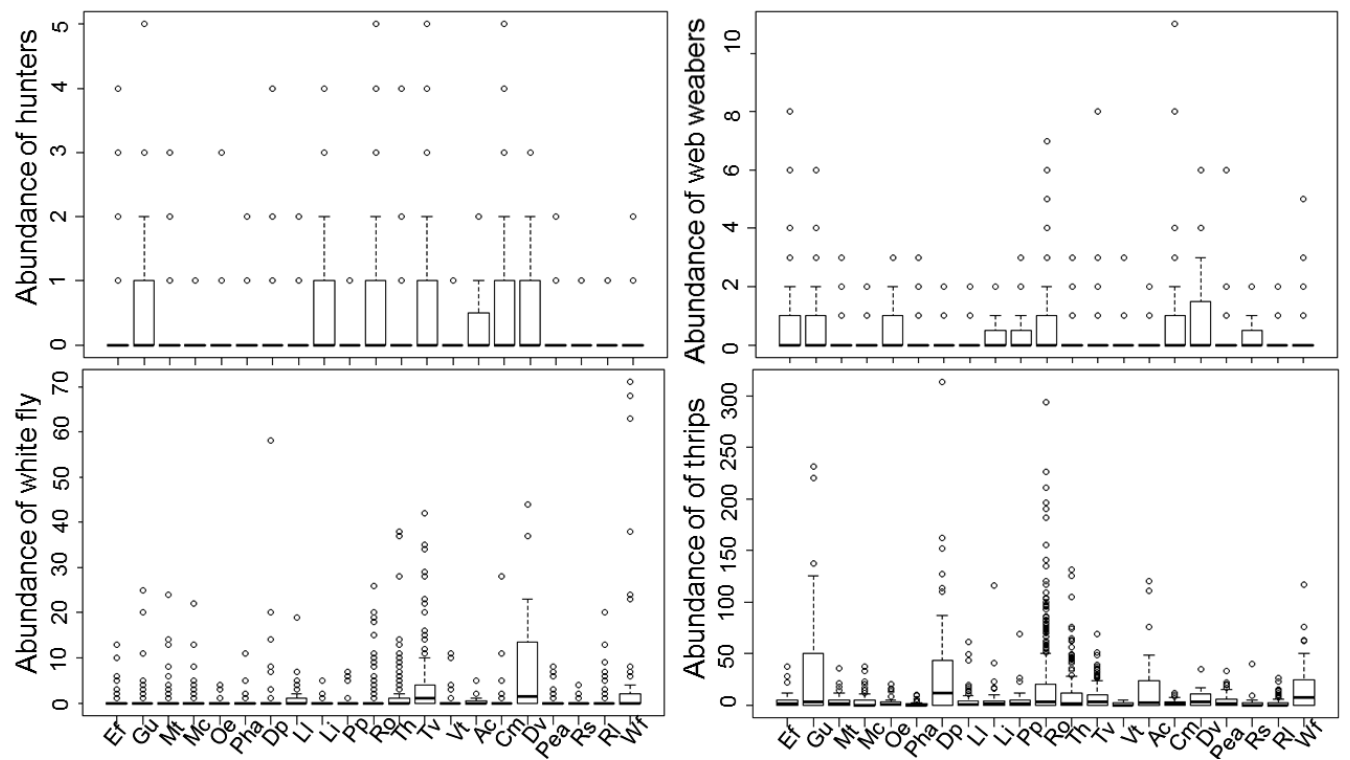

Figure 1. Abundance of hunter spiders, web-weaver spiders and the pests Bemisia tabaci and Frankliniella occidentalis in the different plant species using the plant codes from Table 1. 


\subsection{Redundancy Analysis of Spiders, Pests and Other NEs in Native Plants}

The relationship between spiders, pests and other NEs in native plants was examined using RDA (Figure 2). RDA numerical output showed that all the explanatory variables accounted for $17 \%$ of the variation in arthropod data. Of this $17 \%$, the first two axes accounted for $57 \%$ of the variation, with the first axis alone accounting for $33 \%$. Adjusted R^2 was $15.6 \%$, suggesting that other important data structures were not captured by the model. The RDA correlation triplot showed that B. tabaci, $N$ tenuis, Eretmocerus spp., as well as web-weaver and hunter spiders are situated to the left of the origin, indicating that all species correlate with one another. The abundance levels of these species were found to be highest on the plants, D. viscosa, T. vulgaris and W. frutescens, in the months of October and May. Specifically, Eretmocerus spp. and the predatory bug N. tenuis closely correlated with the nymphal stages of the pest. Adult-stage whiteflies correlated closely with hunter spiders and with web-weavers with intermediate values. With regard to F. occidentalis, the pest and its NEs are situated on the right in the diagram, which indicates that the abundance of spiders (hunters and web-weavers) does not correlate with either F. occidentalis or its NEs. Pest and NEs were more abundant in D. pentaphyllum, R. officinalis and G. umbellata in March. The parasitoid Ceranisus spp. closely correlated with the nymphal stages of the pest, whereas the predatory bug Orius spp., showed a weak positive correlation with the adult stages of $F$. occidentalis. Aeolothrips spp. correlated with adult $F$. occidentalis with intermediate values.

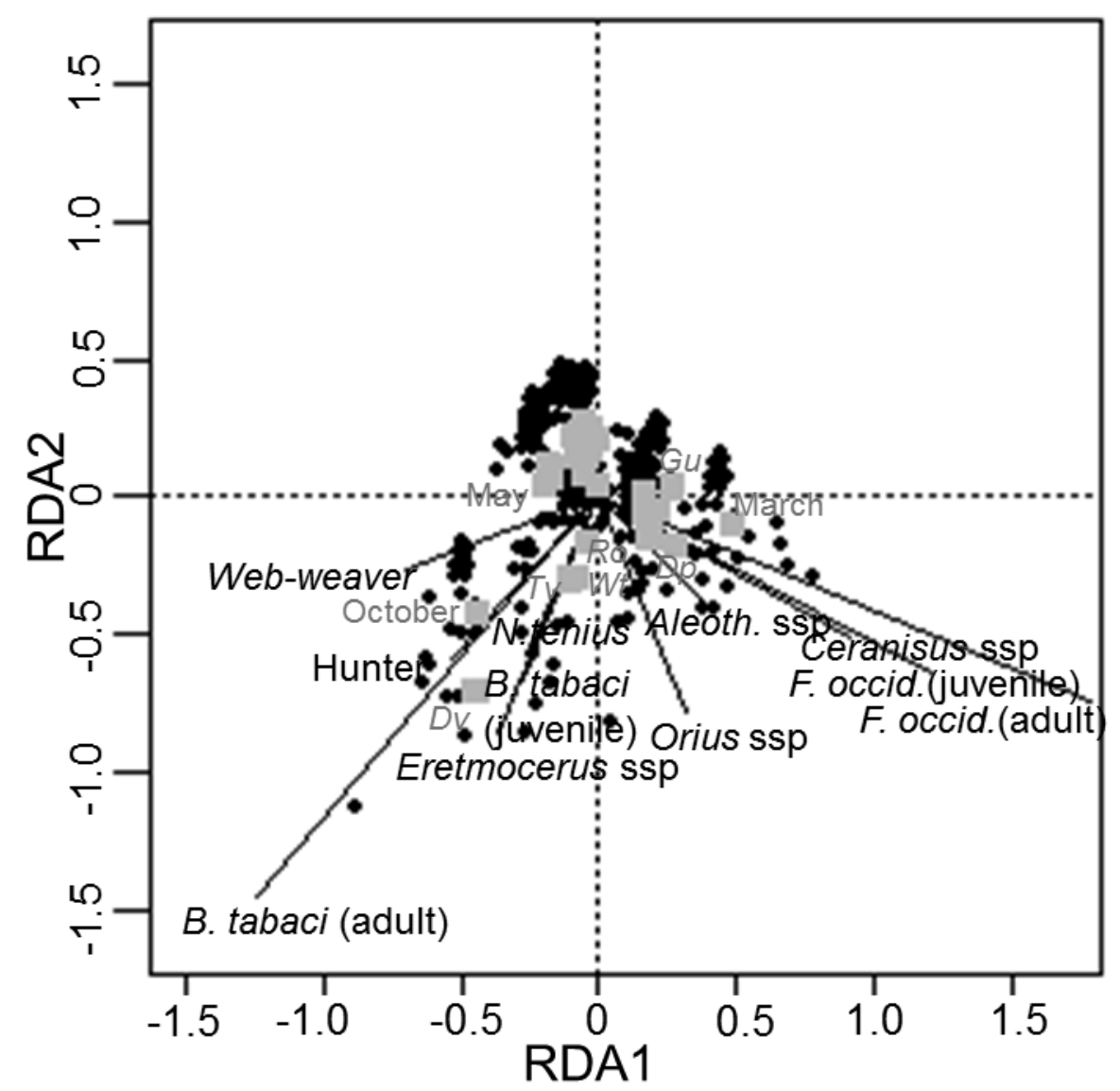

Figure 2. Redundancy Analysis (RDA) ordination diagram showing the variation in the abundance of the spider guilds, the pests Bemisia tabaci and Frankliniella occidentalis and their NEs (-) with respect to two nominal variables: native plants and sampling period in months $(\square)$. Native plants are labelled using plant code from Table 1. 


\section{Discussion}

The aim of this study was to contrast spider abundance in different native shrubs, and the abundance of major pest species and specific biological agents, with a view to using these plants as habitat manipulation resources in Mediterranean greenhouses landscapes. Given the important role usually played by spiders in predatory arthropod communities in agroecosystems, we focused on the role of these plant species to assist spiders and improve BC outdoors. The spider communities collected from native plants belonged to a diverse range of families, although the orb-weaver Neoscona subfusca, as well as hunter spiders, accounted for over $89 \%$ of the spiders captured. The composition of spiders found in the area studied (SE Spain) is in line with studies of agroecosystems in Europe and the USA, where hunters were found to be more complex in terms of species composition, while web-weavers are usually highly uniform, with a numerical predominance of one family/species in many locations [26,43]. The spider assemblage found in native plants could potentially constitute part of an outdoor pest control strategy in Mediterranean greenhouse areas. For instance, philodromids, which prey on a wide variety of pests in fruit orchards, have been shown to be potential biocontrol agents [44], while crab spiders have been reported to be whitefly predators in cotton [33]. Specifically, certain hunter species captured in this study are also important NEs of B. tabaci; for example, Thyene imperalis in cotton crops [32]. Spiderlings of the crab spider Xysticus kochi may be effective predators of $F$. occidentalis in greenhouse pepper crops [37]. The biocontrol potential of small spiders such as web-weavers is generally limited due to low feeding frequency; however, these spiders, capable of building up large populations, could play an important ecological role reducing and stabilizing prey densities [35]. Moreover, webs, which increase the mortality of certain pests, have additional benefits in terms of $B C$, although these pests are not necessarily consumed by spiders [45,46]. Indeed, adult-stage B. tabaci are often trapped in webs built by web-weavers in crops in surrounding greenhouses (Figure 3). The B. tabaci remains have been identified and quantified in the gut of the native Neoscona species in cotton fields [36].

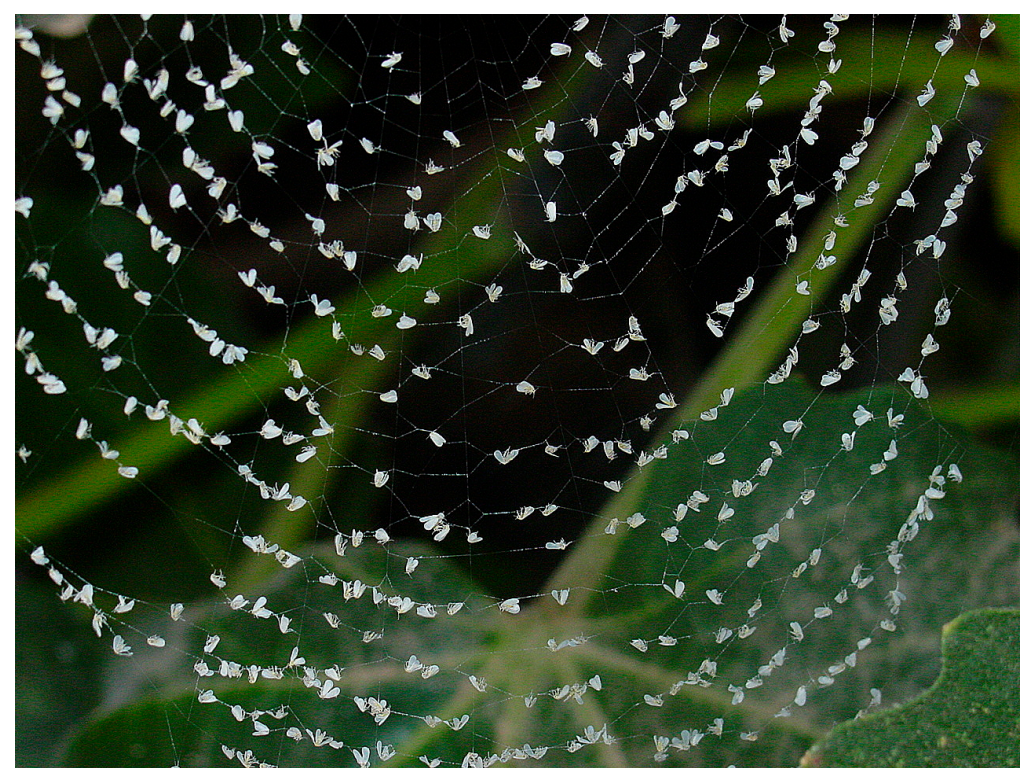

Figure 3. Example of B. tabaci adults trapped in webs built by web-weavers from crops surrounding greenhouses in the study area (Almeria, SE Spain). Photo: Jan van der Blom.

Month of sampling was such a highly significant variable in arthropod populations. Temperatures from late summer create the ideal conditions for whitefly to thrive in native vegetation outdoors. On the other hand, western flower thrips populations build up on native plants throughout the colder season, from December to May. The increase in spider populations was tied to the weather conditions from late-spring and summer, especially for hunter spiders, that remained abundant during 
summer (data not shown). In addition, it is important to note that hunters and web-weavers are more abundant in certain plant species. This information is crucial in ecological terms because it could provide clues as to where and when spiders are likely to be prevalent, indicating co-occurrence between spiders and horticultural pests and thereby show the likelihood of biocontrol. For instance, spiders were mainly found on the small Mediterranean shrub Crithmum maritimum. However, this plant, like other native shrubs such as E. fragilis or L. intricatum, supports very low levels of the two pests, B. tabaci and F. occidentalis (Figure 1), suggesting that spatial co-occurrence between pests and spiders might not occur in certain plant species. Nevertheless, some plants such as G. umbellata, R. officinalis, D. viscosa, T. vulgaris and A. cytisoides were selected by spiders and also supported levels of pests, suggesting that there is spatial co-occurrence between NEs and pests and therefore the probability of biocontrol. In fact, the GAM showed the significant effect of whiteflies on spider's abundance (hunter and web-weavers) and the effect of F. occidentalis on hunter's abundance. Some Thomisidae species have been reported to be potential predators of F. occidentalis in vegetable crops [37]. However, RDA showed no correlation between F. occidentalis and spiders, suggesting that spiders avoid preying on F. occidentalis. Indeed, thrips are rarely found to be part of spider food webs [34,35]. Therefore, the result that the GAM showed that F. occidentalis has a significant effect on hunters is in contrast to the RDA analysis. Adjusted R^2 was $15.6 \%$. Therefore, a few other variables not captured by the model could be expected to be predictors of pest populations outdoors. Such factors could be different farming practices and pests' abundance into greenhouses. The lack of correlation between F. occidentalis and spiders could therefore be partly explained by the different seasonal distribution patterns of spiders in native plants as compared to those of F. occidentalis, which is especially abundant outdoors during the colder months, especially in March. In fact, RDA showed that the abundance levels of F. occidentalis and its NEs were high in March, while spiders were more abundant during the warmer season. Therefore, it is possible that spiders and thrips co-occur for biocontrol only in a short period of time. Regarding the whitefly, hunters exhibit a strong positive relationship with adult and nymphal-stage $B$. tabaci, which points to the sessile juveniles of the pest as a suitable part of the spiders' diet. The intermediate relationship reported between web-weavers and the two stages of whitefly could be explained by the prey suitability of $B$. tabaci for this spider guild, suggesting that web-weavers might prefer to feed on adult-stage rather than nymphal stage of the pest. Most web-weavers largely depend on relatively few prey groups available in large numbers in a particular environment, whereas hunters feed on both moving and sessile prey as a result of their mobile foraging strategy [34]. Regarding the NEs, the positive relationship between spiders (hunters and web-weavers) and whitefly NEs may also indicate consumption of the predatory bug $N$. tenuis or the parasitized nymphal-stage by spiders and thus unidirectional intraguild predation (spiders on whitefly NEs). For instance, web-weavers are known to mainly capture minute soft-bodied insects, with Heteroptera appearing to be a more suitable source of food for hunters [34]. Similarly, it has been found that generalist predators, such as carabid and staphylinid beetles, as well as linyphiid spiders, may disrupt parasitoid aphid control through direct and coincidental intraguild predation [47]. Nevertheless, the interaction between spiders and whitefly NEs supports the hypothesis of positive NE-whitefly interactions rather than intraguild predation between spiders and whitefly NEs. In fact, RDA showed that pest availability is a strong predictor of the abundance of NEs in native plants.

Finally, this study has shown that certain native plants, such us A. cytisoides, C. martimum, D. viscosa, E. fragilis, G. umbellata, L. intricatum, O. europaea, P. purpurea, R. officinalis, R. sphaerocarpa and T. vulgaris, may be especially attractive for hosting spiders. The density and diversity of plant-dwelling spiders appears to be closely tied to the architectural variations in the vegetation [48]. Plants are often important for spiders as sites for building webs, for sheltering against desiccation or natural enemies, for foraging, and for mating and oviposition [48-51]. Therefore, richness and composition of spider species on plants are influenced by the structural complexity and diversity of these plants. Vegetation with sufficient interspaces, greater height, lower leaf and branch densities favour the establishment of web weavers [48-50]. This was the case with, for instance, G. umbellata, E. fragilis, 
O. europaea and R. sphaerocarpa, which supported a higher abundance of web-weavers. On the other hand, low and sparse plants support a lower spider population. Exception to this rule in this study occurred in some low plants with high density of spiders, particularly hunters, like C. maritimum and T. vulgaris. This, however, could be explained by favourable microclimate or by presence of inflorescences (i.e., prey availability). It is known that thomisid spiders select plant-determined microhabitat (i.e., size and shape of leaves); and inflorescences can attract more guild spiders, including hunters, than vegetative branches [52]. Some plants of this study such as G. umbellata, R. officinalis, D. viscosa, T. vulgaris and A. cytisoides hosted spiders and pests. These five plants have already been identified for harboring pests and specific NEs populations' outdoors [22]. Therefore, inclusion of plants species supporting spiders in hedgerows between greenhouses should optimize natural pest control whilst maintaining conservation value. By benefiting spiders, they will predate more whiteflies and thrips, and this will reduce their immigration into the greenhouses and, therefore, viruses transmitted by pests into crops. Since viruses that are transmitted by whitefly and western flower thrips tend to be found at lower densities in native flora than in crops [17], these plantations around greenhouses may act as phytosanitary barriers for pests and diseases that affect greenhouse horticultural crops. In agroecosystems based on annual crops, several non-host plants have been tested as barrier crops or intercrops to reduce whitefly colonization and virus transmission among main crops [53-55]. As the study was conducted with different experimentally planted shrub species, further field research using these candidate plants as plantations in the vicinity of greenhouses is required to confirm these results.

\section{Conclusions}

A group of 11 native shrub species, A. cytisoides, C. martimum, D. viscosa, E. fragilis, G. umbellata, L. intricatum, O. europaea, P. purpurea, R. officinalis, R. sphaerocarpa and T. vulgaris, was found to support a large number of spiders. Specifically, E. fragilis, O. europaea and $R$. sphaerocarpa supported a larger number of web-weavers, while T. vulgaris and A. cytisoides supported more hunters. Only five of them, G. umbellata, R. officinalis, D. viscosa, T. vulgaris and A. cytisoides, hosted higher abundance of spiders and pests. Abundance of both pests had a significant effect on the abundance of hunter spiders, while the abundance of B. tabaci, unlike F. occidentalis, affected the abundance of web-weavers. Results also suggest that spiders can offer a complementary niche: web-weavers may play an important role as adult-stage predators of whitefly, whereas hunters may play as predators of nymphal stages of the pest. Nevertheless, it is important to highlight the positive correlation detected between spiders and whitefly NEs. This suggests that the predatory bug N. tenuis and immobile stages of whiteflies (parasitized or not by Eretmocerus spp.) could be potential prey for spiders, a hypothesis which is worthy of further study in the future. In conclusion, the results show that there is a positive relationship between spider and pest abundance on some plants, suggesting potential for biological control due to spatial and temporal occurrence. This relationship was higher for Bemisia tabaci than for Frankliniella occidentalis. On the basis of these results, future field trials are needed to see whether conservation strategies involving the establishment of native plants suitable for spiders outdoors may provide changes or reduction on pest populations, especially those of $B$. tabaci.

Acknowledgments: The authors would like to thank the local Junta de Andalucía forest nursery network (Red de Viveros Forestales) for supplying the native plants and V. Schwarzer for designing the natural patch and for providing botanical assistance. The study was supported by the RECUPERA 2020 Project funded by the Spanish MINECO and EU-FEDER program, by TRANSFORMA (PP.TRA.TRA201600.9). The research carried out by E. Rodríguez was supported by the DOC-INIA program funded by INIA-FEDER. We also wish to thank Michael O'Shea for proofreading the text.

Author Contributions: E. Rodríguez, M. González, E. Benítez and M. Campos conceived and designed the experiments; E. Rodríguez, M. González, G. Clemente-Orta and E. De Mas performed the experiments; B. Cotes analyzed the data; E. Rodríguez, M. González and B. Cotes contributed reagents/materials/analysis tools; E. Rodríguez and B. Cotes wrote the paper.

Conflicts of Interest: The authors declare no conflict of interest. 


\section{References}

1. Bommarco, R.; Kleijn, D.; Potts, S.G. Ecological intensification: Harnessing ecosystem services for food security. Trends Ecol. Evol. 2013, 28, 230-238. [CrossRef] [PubMed]

2. Gurr, G.M.; Lu, Z.; Zheng, X.; Xu, H.; Zhu, P.; Chen, G.; Yao, X.; Cheng, J.; Zhu, Z.; Catindig, J.L.; et al. Multi-country evidence that crop diversification promotes ecological intensification of agriculture. Nat. Plants 2016, 2, 16014. [CrossRef] [PubMed]

3. Rusch, A.; Chaplin-Kramer, R.; Gardiner, M.M.; Hawro, V.; Holland, J.; Landis, D.; Thies, C.; Tscharntke, T.; Weisser, W.W.; Winqvist, C.; et al. Agricultural landscape simplification reduces natural pest control: A quantitative synthesis. Agric. Ecosyst. Environ. 2016, 221, 198-204. [CrossRef]

4. Bianchi, F.J.J.A.; Booij, C.J.H.; Tscharntke, T. Sustainable pest regulation in agricultural landscapes: A review on landscape composition, biodiversity and natural pest control. Proc. R. Soc. Lond. B Biol. Sci. 2006, 273, 1715-1727. [CrossRef] [PubMed]

5. Landis, D.A.; Wratten, S.D.; Gurr, G.M. Habitat management to conserve natural enemies of arthropod pests in agriculture. Annu. Rev. Entomol. 2000, 45, 175-201. [CrossRef] [PubMed]

6. Snyder, W.E.; Tylianakis, J.M. The ecology of biodiversity-biocontrol relationships. In Biodiversity and Insect Pests—Key Issues for Sustainable Management; Gurr, G.M., Wratten, S.D., Snyder, W.E., Read, D.M.Y., Eds.; Wiley: Chichester, UK, 2012; pp. 23-40. ISBN 978-0-470-65686-0.

7. Straub, C.S.; Finke, D.L.; Snyder, W.E. Are the conservation of natural enemy biodiversity and biological control compatible goals? Biol. Control 2008, 45, 225-237. [CrossRef]

8. Gaba, S.; Bretagnolle, F.; Rigaud, T.; Philippot, L. Managing biotic interactions for ecological intensification of agroecosystems. Front. Ecol. Environ. 2014, 2, 29. [CrossRef]

9. Giagnocavo, C.; Headquarters, U. The Almería Agricultural Cooperative Model: Creating Successful Economic and Social Communities; International Year of Cooperatives Side-Event with the Commission for Social Development "The Role of Coopera-Tives in Poverty Eradication"; UN Headquarters: New York, NY, USA, 2012.

10. Mendoza-Fernández, A.; Martínez-Hernández, F.; Pérez-García, F.; Garrido-Becerra, J.; Benito, B.; Salmerón-Sánchez, E.; Guirado, J.; Merlo, M.; Mota, J. Extreme habitat loss in a Mediterranean habitat: Maytenus senegalensis subsp. europaea. Plant Biosyst. 2015, 149, 503-511. [CrossRef]

11. Gilbertson, R.L.; Batuman, O.; Webster, C.G.; Adkins, S. Role of the insect supervectors Bemisia tabaci and Frankliniella occidentalis in the emergence and global spread of plant viruses. Annu. Rev. Virol. 2015, 2, 67-93. [CrossRef] [PubMed]

12. Lozano, R.; Diánez, F.; Camacho, F. Evolution of the phytosanitary control system in the intensive horticulture model of high yield in Almería (2005-2008). J. Food Agric. Environ. 2010, 8, 330-338.

13. Van Lenteren, J.C. The state of commercial augmentative biological control: Plenty of natural enemies, but a frustrating lack of uptake. Biocontrol 2012, 57, 1-20. [CrossRef]

14. Glass, R. Biological control in the greenhouses of Almeria and challenges for a sustainable intensive production. Outlooks Pest Manag. 2012, 23, 276-279. [CrossRef]

15. Perdikis, D.; Kapaxidi, E.; Papadoulis, G. Biological control of insect and mite pests in greenhouse solanaceous crops. Eur. J. Plant Sci. Biotechnol. 2008, 2, 125-144.

16. Rodríguez, E.; Schwarzer, V.; Van der Blom, J.; Cabello, T.; González, M. The selection of native insectary plants for landscaping in greenhouse areas of SE Spain. Landsc. Manag. Funct. Biodivers. IOBC/WPRS Bull 2012, 75, 73-76.

17. Rodríguez, E.; van der Blom, J.; González, M.; Sánchez, E.; Janssen, D.; Ruiz, L.; Elorrieta, M.A. Plant viruses and native vegetation in Mediterranean greenhouse areas. Sci. Hortic. 2014, 165, 171-174. [CrossRef]

18. Fiedler, A.K.; Landis, D. Attractiveness of Michigan native plants to arthropod natural enemies and herbivores. Environ. Entomol. 2007, 36, 751-765. [CrossRef] [PubMed]

19. Isaacs, R.; Tuell, J.; Fiedler, A.; Gardiner, M.; Landis, D. Maximizing arthropod-mediated ecosystem services in agricultural landscapes: The role of native plants. Front. Ecol. Environ. 2009, 7, 196-203. [CrossRef]

20. James, D.G.; Seymour, L.; Lauby, G.; Buckley, K. Beneficial insects attracted to native flowering buckwheats (Eriogonum michx) in central Washington. Environ. Entomol. 2014, 43, 942-948. [CrossRef] [PubMed]

21. Morandin, L.A.; Long, R.F.; Kremen, C. Hedgerows enhance beneficial insects on adjacent tomato fields in an intensive agricultural landscape. Agric. Ecosyst. Environ. 2014, 189, 164-170. [CrossRef] 
22. Rodríguez, E.; González, M.; Paredes, D.; Campos, M.; Benítez, E. Selecting native perennial plants for ecological intensification in Mediterranean greenhouse horticulture. Bull. Entomol. Res. 2017, 1-11. [CrossRef] [PubMed]

23. Turnbull, A.L. Ecology of the true spiders (Araneomorphae). Annu. Rev. Entomol. 1973, 18, 305-348. [CrossRef]

24. Wise, D. Spiders in Ecological Webs; Cambridge University: New York, NY, USA, 1993; pp. 48-50, ISBN-13 978-0521310611.

25. Marc, P.; Canard, A.; Ysnel, F. Spiders (Araneae) useful for pest limitation and bioindication. Agric. Ecosyst. Environ. 1999, 74, 229-273. [CrossRef]

26. Nyffeler, M.; Sunderland, K.D. Composition, abundance and pest control potential of spider communities in agroecosystems: A comparison of European and us studies. Agric. Ecosyst. Environ. 2003, 95, 579-612. [CrossRef]

27. Riechert, S.E.; Lockley, T. Spiders as biological control agents. Annu. Rev. Entomol. 1984, 29, $299-320$. [CrossRef]

28. Schmitz, O.J. Effects of predator hunting mode on grassland ecosystem function. Science 2008, 319, $952-954$. [CrossRef] [PubMed]

29. Bucher, R.; Menzel, F.; Entling, M.H. Risk of spider predation alters food web structure and reduces local herbivory in the field. Oecologia 2015, 178, 571-577. [CrossRef] [PubMed]

30. Finke, D.L.; Denno, R.F. Predator diversity dampens trophic cascades. Nature 2004, 429, 407-410. [CrossRef] [PubMed]

31. Hodge, M.A. The implications of intraguild predation for the role of spiders in biological control. J. Arachnol. 1999, 351-362.

32. Ghavami, S. The potential of predatory spiders as biological control agents of cotton pests in Tehran provinces of Iran. Asian J. Exp. Sci. 2008, 22, 303-306.

33. Hagler, J.R.; Naranjo, S.E. Use of a gut content ELISA to detect whitefly predator feeding activity after field exposure to different insecticide treatments. Biocontrol Sci. Technol. 2005, 15, 321-339. [CrossRef]

34. Nyffeler, M. Prey selection of spiders in the field. J. Arachnol. 1999, 317-324.

35. Nyffeler, M.; Sterling, W.; Dean, D. How spiders make a living. Environ. Entomol. 1994, 23, $1357-1367$. [CrossRef]

36. Zhang, G.F.; Lü, Z.C.; Wan, F.H.; Lövei, G.L. Real-time PCR quantification of Bemisia tabaci (Homoptera: Aleyrodidae) b-biotype remains in predator guts. Mol. Ecol. Resour. 2007, 7, 947-954. [CrossRef]

37. Zrubecz, P.; Toth, F.; Nagy, A. Is Xysticus kochi (Araneae: Thomisidae) an efficient indigenous biocontrol agent of Frankliniella occidentalis (Thysanoptera: Thripidae)? Biocontrol 2008, 53, 615-624. [CrossRef]

38. Piñero, F.; Tinaut, A.; Aguirre-Segura, A.; Miñano, J.; Lencina, J.; Ortiz-Sánchez, F.; Pérez-López, F. Terrestrial arthropod fauna of arid areas of SE Spain: Diversity, biogeography, and conservation. J. Arid Environ. 2011, 75, 1321-1332. [CrossRef]

39. Zuur, A.F.; Ieno, E.N.; Elphick, C.S. A protocol for data exploration to avoid common statistical problems. Methods Ecol. Evol. 2010, 1, 3-14. [CrossRef]

40. Yee, T.W.; Mitchell, N.D. Generalized additive models in plant ecology. J. Veg. Sci. 1991, 2, 587-602. [CrossRef]

41. R Development Core Team. R: A Language and Environment for Statistical Computing; Foundation for Statistical Computing: Vienna, Austria, 2014.

42. Wood, S. Generalized Additive Models: An Introduction with R; CRC Press: Boca Raton, FL, USA, 2006; ISBN 9781584884743.

43. Nobre, T.; Meierrose, C. In The species composition, within-plant distribution, and possible predatory role of spiders (Araneae) in a vineyard in southern Portugal. In Proceedings of the 18th European Colloquium of Arachnology; Gajdos, P., Pékar, S., Eds.; Ekologia: Bratislava, Slovakia, 2000; pp. 193-200.

44. Michalko, R.; Pekár, S. The biocontrol potential of Philodromus (Araneae, Philodromidae) spiders for the suppression of pome fruit orchard pests. Biol. Control 2015, 82, 13-20. [CrossRef]

45. Riechert, S. The use of behavioral ecotypes in the study of evolutionary processes. In Geographic Variation in Behavior: Perspectives on Evolutionary Mechanisms; Foster, S.A., Endler, J.A., Eds.; Oxford University Press: Oxford, UK, 1999; pp. 3-32.

46. Sunderland, K. Mechanisms underlying the effects of spiders on pest populations. J. Arachnol. 1999, 27, 308-316. 
47. Traugott, M.; Bell, J.; Raso, L.; Sint, D.; Symondson, W.O. Generalist predators disrupt parasitoid aphid control by direct and coincidental intraguild predation. Bull. Entomol. Res. 2012, 102, 239-247. [CrossRef] [PubMed]

48. Rypstra, A.N.; Carter, P.E.; Balfaour, R.A.; Marshall, S.D. Architectural features of agricultural habitats and their impact on the spiders inhabitants. J. Arachnol. 1999, 27, 371-377.

49. Greenstone, M.H. Determinats of web spiders species diversity: Vegetation structural diversity vs. prey availability. Oecologia 1984, 62, 299-304. [CrossRef] [PubMed]

50. Nentwig, W. Weedy plant species and their beneficial arthropods: Potential for manipulations in field crops. In Enhancing Biological Control: Habitat Management to Promote Natural Enemies of Agricultural Pests; Pickett, C.H., Bugg, R.L., Eds.; UC Press: Berkeley, CA, USA, 1998; pp. 49-72.

51. Romero, G.Q.; Vasconcellos-Neto, J. The effects of plant structure on the spatial and microspatial distribution of a bromeliad-living jumping spider (Salticidae). J. Anim. Ecol. 2005, 74, 12-21. [CrossRef]

52. Souza, A.L.T.D.; Martins, R.P. Distribution of plant-dwelling spiders: Inflorescences vs. vegetative branches. Austral Ecol. 2004, 29, 342-349. [CrossRef]

53. Sharma, S.R.; Verma, A. Effect of cultural practices on virus infection in cowpea. Z. Acker Planzenbau 1984, 153, 23-31.

54. Smith, H.A.; McSorley, R. Potential of field corn as a barrier cropland eggplant as a trap crop for management of Bemisia argentifolii (Homoptera: Aleyrodidae) on common bean in North Florida. Fla. Entomol. 2000, 83, 145-158. [CrossRef]

55. Rataul, H.S.; Gill, C.K.; Brar, S. Use of barrier crop and some cultural measures in the management of yellow mosaic virus on soybean. J. Res. Punjab Agric. Univ. 1989, 26, 227-230.

(C) 2018 by the authors. Licensee MDPI, Basel, Switzerland. This article is an open access article distributed under the terms and conditions of the Creative Commons Attribution (CC BY) license (http:/ / creativecommons.org/licenses/by/4.0/). 